\title{
Physico-chemical Characterization of Clayey Materials Consumed by Geophagism in Locality of Sabga (North-western Cameroon): Health Implications
}

\author{
Kenne Kalguem Elvis Duplex \\ Wouatong Armand Sylvain Ludovic \\ Department of Earth Sciences \\ Faculty of Sciences \\ University of Dschang, Cameroon \\ Njopwouo Daniel \\ Department of Inorganic Chemistry \\ Faculty of Sciences \\ University of Yaoundé I, Cameroon \\ Ekosse Georges Ivo \\ Directorate of Research and Innovation \\ University of Venda, Zambia
}

\begin{abstract}
Geophagy is the habitual and intentional consumption of earth and clay deposits by animals and humans. Physicochemical properties of geophagic clayey materials from Sabga were determined in order to appreciate their capability to perform the functions for which they are consumed and possible consequences of the practice in humans. Among the properties investigated are: Tests conducted included colour, particle size distribution (PSD), consistency limits, pH, Electrical Conductivity (EC), Water Retention Capacity (WRC), Organic Matter Content (OMC) and Cation Exchange Capacity (CEC). Results show that the pH values range from 4.1 to 5.6. EC (0.01 to 0.02) and OMC values are low (3.99 to 5.10\%). The WRC values are generally very high (above 50\%). The samples were observed to have low CEC, ranging from 26.96 to 43.28. Geochemical data indicated that geophagic materials clayey are composed of $\mathrm{SiO}_{2}$ content ranging from $41.86 \%$ to $64.84 \%, \mathrm{Al}_{2} \mathrm{O}_{3}$ values varies from $12.75 \%$ to $23.41 \%, \mathrm{Fe}_{2} \mathrm{O}_{3}$ values varies from $4.14 \%$ to $13.29 \%$, $\mathrm{K}_{2} \mathrm{O}$ content values varies from 0.28 to $2.43 \%, \mathrm{MgO}$ content varies from $0.00 \%$ to $0.36 \%, \mathrm{CaO}$ ranges between $0.04 \%$ and $0.56 \%, \mathrm{Na}_{2} \mathrm{O}$ values varies from 0.10 to $1.78 \%$, $\mathrm{TiO}_{2}$ values varies from $0.22 \%$ to $0.95 \%, \mathrm{P}_{2} \mathrm{O}_{3}$ values varies from 0.02 to $0.05 \%$ and $\mathrm{MnO}$ content ranges from $0.01 \%$ to $0.12 \%$. These values indicate that the geophagic clayey materials are essentially siliceous aluminosilicates. XRD revealed that geophagic clayey materials contain several minerals and the main reflections of the clay minerals identified were smectite and kaolinite. The peaks of other minerals are $K$ feldspars, plagioclases, hematite, goethite and quartz. The peaks of traces are ilmenite. The present studies have shown that the high clay content and the high water retention capacity may help to alleviate the symptoms of diarrhea because of its absorption ability. Because of the low CEC of the soils, adsorption of cations $H^{+}$from the stomach may not be possible for the relief of the gastric acidity. But from results of available elements, there is tendency for some of the cations to be released and absorbed into the gastrointestinal tract. Possible human health short coming in the ingestion of the geophagic clayey materials would include dental enamel damage and perforation of the sigmoid colon. These clayey soils, due to their colour are inferred to contain different forms of iron oxide minerals including hematite and goethite, which may help alleviate symptoms of iron deficiency anaemia.
\end{abstract}

Keywords: Characterization, Geophagic clayey materials, Health Implications, Sabga

\section{Introduction}

Geophagia, the habit of deliberate consumption of earthy material (Dominy et al., 2004), has been reported to be in existence as early as the fourth century. 
The practice of geophagia has been reported in several countries across continents including Africa (South Africa, Cameroon, Democratic Republic of Congo, Nigeria, Swaziland, Tanzania and Uganda), Asia (China, India, Philippines, and Thailand) and the Americas (Ngole et al., 2010; Bonglaisin et al., 2011). Several reasons have been advanced to justify geophagial behavior; some of which are cultural, others medicinal and nutritional (Carretero, 2002; Ekosse et al., 2010).

Consumers of clays/soils believe that clay consumption prevents excessive secretion of saliva and reduces nausea, provides them with micronutrients, which help them during pregnancy and in turn helps in the physiological development of their fetus. They emphasize that a child whose mother consumed clay during her pregnancy tends to have natural beauty and well developed skin. According to Ngole and Ekosse (2012) the positive and negative effects of geophagia may vary depending on the physico-chemistry, mineralogy and geochemistry of the ingested materials clayey. In Cameroon, several localities abound in edible geophagic materials clayey. We have kaolinite of Kousserie, Mayouom, Dschang and Mokolo, smectite of Baba and hallosite of Balengou (Douola, 2008; Njopwouo et al., 1998; Diko et al., 2014; Diko and Ekosse, 2014; Banenzoue, 2017). There is a very limited documentation of the geology, mineralogy and geochemistry of the geophagic clays in Cameroon. Studies on soils ingested by humans could provide clues on the relationship between health of geophagic individuals and soil physico-chemical, mineralogical and geochemical properties. On the basis of this premise, the objectives of this study are to physico-chemically and mineralogically characterize geophagic clayey materials from the locality of Sabga, North West region of Cameroon, and to ascertain possible health implications on the geophagic individuals.

\section{The local geology of the study area}

The study area is located in Sabga, within coordinates $5^{\circ} 58^{\prime}$ to $6^{\circ} 03^{\prime}$ and $10^{\circ} 19^{\prime}$ to $10^{\circ} 25^{\prime}$ (figures 1 and 2), between Ngoketunjia and Mezam divisions the North West of Cameroon. The area under study is part of the Bamenda Mountains, situated on the Cameroon Volcanic Line (CVL). Sabga locality is located between the Bamboutos Mountains to the South West and the Oku massive to the North West. This volcanic province is made up of both mafic and felsic rocks lying on a panafrican or older basement (Kamgang et al., 2008). On the one hand, the felsic lavas are mainly represented by trachytes, with subordinated benmoreites and alkaline to peralkaline rhyolites (Kamgang et al., 2007). On the other hand, the mafic rocks are basalts to mugearites (Kamgang et al., 2008). Montmorillonite and kaolinite, which were the mains desirable minerals component of the geophagic clayey materials, were geochemically derived from surrounding trachytes (figure 3).

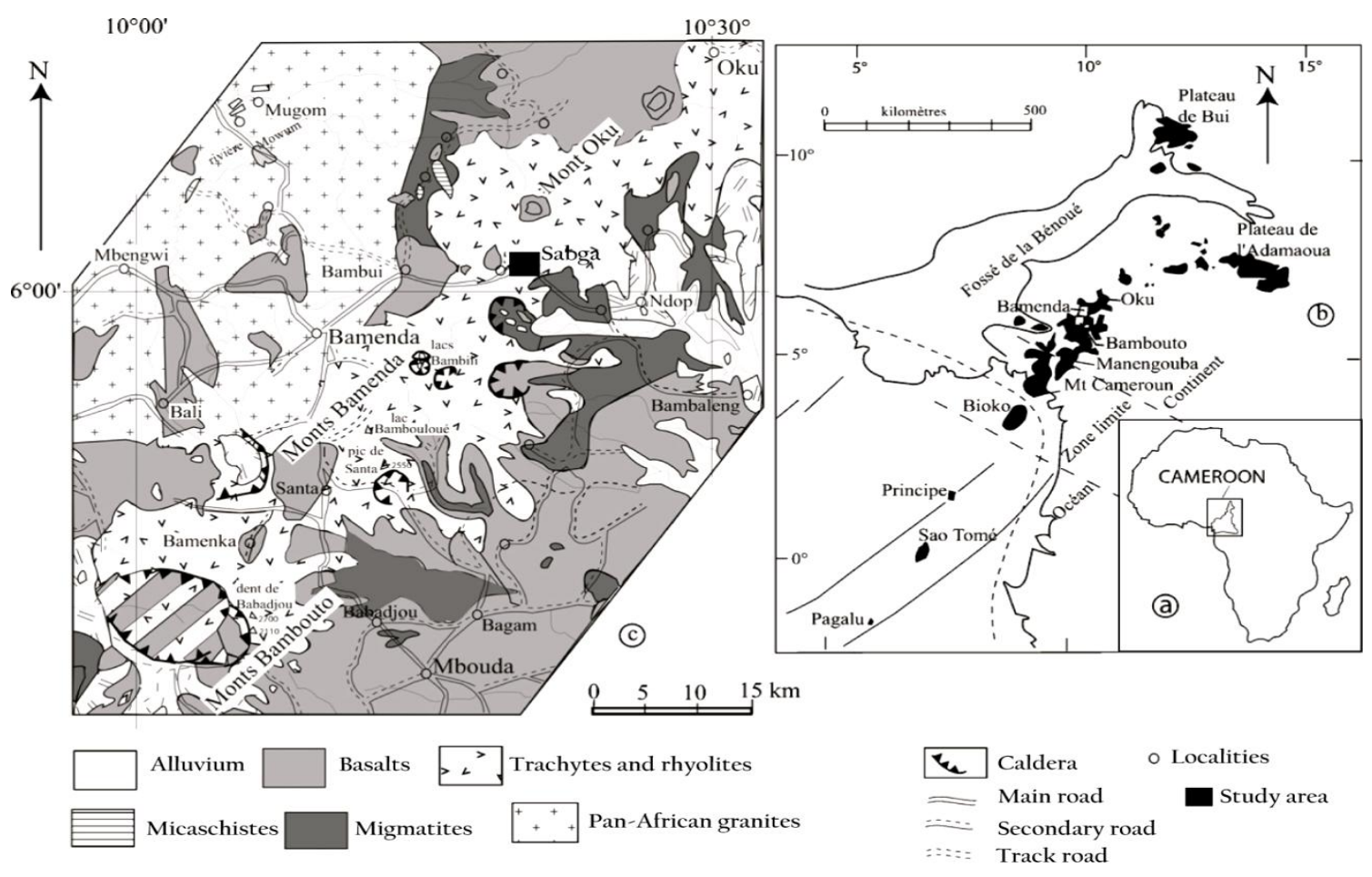


Figure 1: Geological map of the Bamenda Mountains showing the location of study area (modified from Kamgang et al., 2008)

\section{Materials and Methods}

Five clay samples were collected from Sabga mining sites, as shown in figure 2. The sampling location map is shown in figure 3.
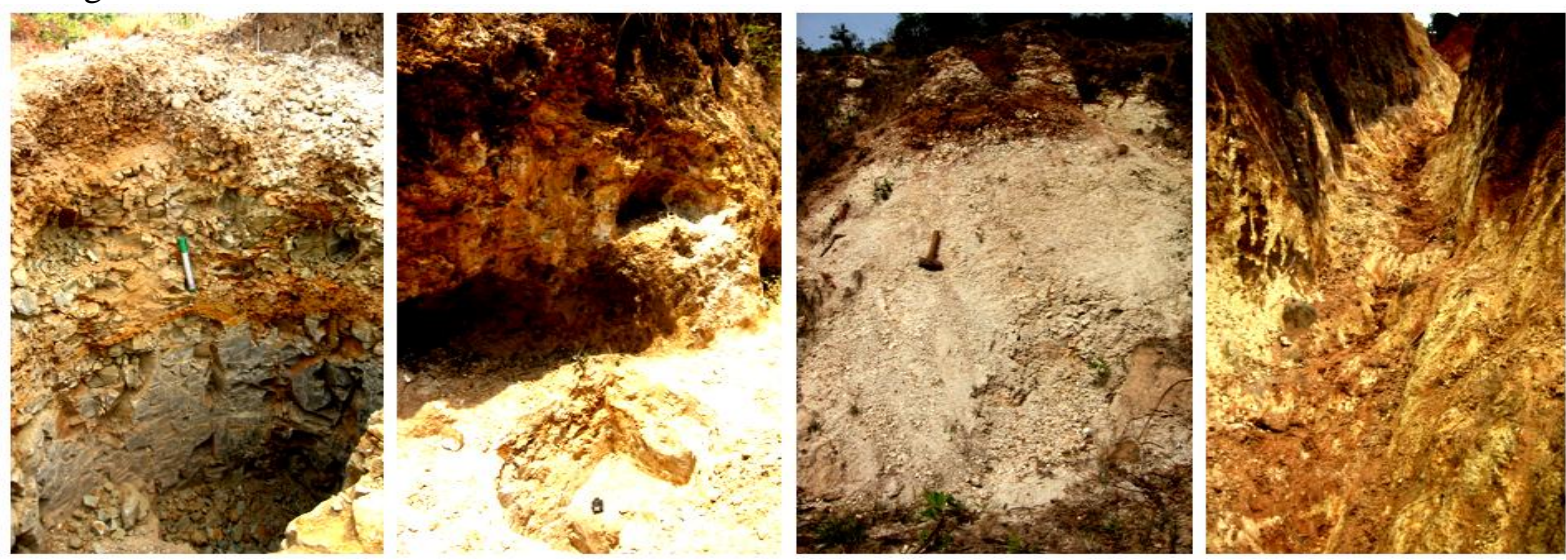

Figure 2: Sabga clay deposit mine

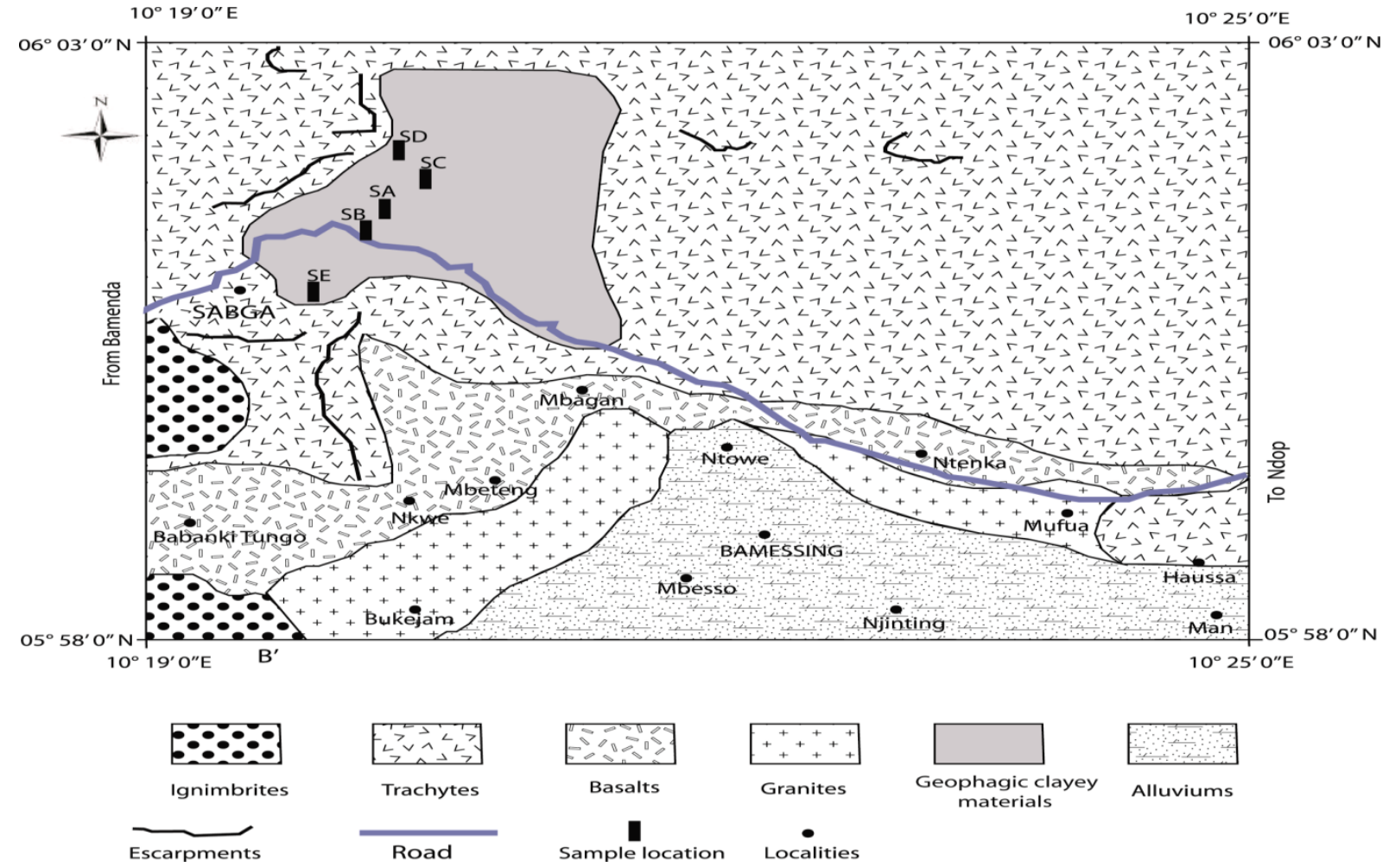

Figure 3: Geological map of Sabga showing the different sample locations (shown by Rectangle blacks).

\section{Physico-chemical analyses}

The samples were air-dried after collection, according to the methods of Van Reeuwijk (2002). They were then gently disaggregated using an agate mortar and pestle. Analyses for colour, particle size distribution, Atterberg's Limits, pH, Water Retention Capacity (WRC), Electrical Conductivity (EC), Organic Matter contents (OMC) and Cation Exchange Capacity (CEC) was determined on all the samples. The analyses were carried out at laboratory of soil science of the faculty of agronomy and agricultural science of the University of Dschang, Cameroon. Colour determination was done by visually comparing the sample colour with those in the Munsell soil colour charts (2012) to obtain the hue, value, chroma and colour of the samples. 
The particle size distribution of the geophagic clayey materials samples were determined by the hydrometer method as described by Van Reevwijk (2002).The Atterberg's Limits were obtained by the Casagrande method according to ASTM norm D-4318. The $\mathrm{pH}$ of the clayey soil samples was determined both in a 1:2.5 clayey soilwater suspension ratio according to the methods advanced by Van Reevwijk (2002). Electrical Conductivity (EC) of samples was measured on the saturated paste extract of each sample as described in the United States Soil Survey Laboratory Manual (1996). Water Retention Capacity (WRC) of the samples was determined using the methods advanced by Forster. The organic matter content (OMC) is obtained by determination of organic carbon (OC). OC was determined by the method of Walkey and Black after mineralisation by oxidation with the potassium dichromate and the strongly concentrated sulphuric acid. The organic matter content (OMC) is then deduced by equation: $\% \mathrm{OM}=1.74 * \%$ OC. The Barium chloride compulsive exchange method of Cation Exchange Capacity (CEC) determination as described by Gilman and Sumpler was employed for all the geophagic clayey materials samples.

\section{Mineralogy}

The X-ray diffraction (XRD) patterns were obtained with a Bruker D8- Avance Eco 1Kw diffractometer (Copper $\mathrm{K} \alpha$ radiance, $\lambda=1.5418 \AA, \mathrm{V}=40 \mathrm{KV}, \mathrm{I}=25 \mathrm{~mA}$ ) with Lynxeye Xe energy dispersive detector in the laboratory of "Argiles, Géochimie et Environments sédimentaires (AGEs)" at the University of Liège, Belgium. The analyses were carried out on the bulk material (non-oriented powder with grinded particles $<250 \mu \mathrm{m}$ ) and on the clay fraction $(<2 \mu \mathrm{m})$ according to a protocol of Moore and Reynolds (1997). The XRD patterns were recorded over the $2-70^{\circ} 2 \theta$ angular range for the bulk material and between $2^{\circ}$ and $30^{\circ} 2 \theta$ for the clay fraction. The step sizes considered for both type of analysis were $0.02^{\circ}$ and $0.009^{\circ} 2 \theta$ respectively, whereas the time per step chosen were 0.25 to 0.5 seconds, respectively. The primary optic is motorized in order to illuminate a fixed sample length, whatever the angular position (16 $\mathrm{mm}$ for bulk, $12 \mathrm{~mm}$ for clays).

\section{Semi-quantitative mineralogical analysis}

This method uses the height of a diagnostic peak multiplied by a corrective factor (Cook et al., 1975; Boski et al., 1998) together with the so-called $100 \%$ approach (the term $100 \%$ approach connotes that the sum of all phase quantities identified in a sample is $100 \%$ ). The common reflection of clays at $4.47 \AA$ is multiplied by a corrective factor of 20 to give estimate of the total clays in the bulk sample (Table 2). For the semi-quantification of the different clay minerals and non-clay mineral, the estimation of kaolinite and smectite were based on the height of 001 reflections (at $\sim 7$ and $\sim 14 \AA$, respectively) with correction factor of 0.7 and 0.25 , respectively (Fagel et al., 2003) on glycolated specimens, estimation of quartz, feldspars, plagioclase, goethite and hematite were based on the height of 001 reflections $(3,35,3.24,3.20,4.97$ and $2.69 \AA$, respectively) with correction factor of $1,4.3,2.8,7$ and $\sim 3.33$ respectively.

\section{Geochemistry}

The chemical analyses were obtained through X-ray Fluorescence (XRF) spectrometry (Bruker S8 Tiger 4kW spectrometer). The samples were molded in borax $\left(\mathrm{Na}_{2} \mathrm{~B}_{4} \mathrm{O}_{7} 10 \mathrm{H}_{2} \mathrm{O}\right)$ and the determination of major elements derived according to calibration against standards. Chemical analyses were analysed in the laboratory of "pétrologie sédimentaire (PETROSED)" at the University of Liège in Belgium.

\section{Results}

\section{Geochemistry of geophagic clayey materials}

The results of the geochemical analysis as shown in table 3 indicate that the geophagic clayey materials from Sabga locality were composed of $\mathrm{SiO}_{2}$ content of $41.86 \%$ to $64.84 \% ; \mathrm{Al}_{2} \mathrm{O}_{3}$ values of $12.75 \%$ to $23.41 \% ; \mathrm{Fe}_{2} \mathrm{O}_{3}$ values of $4.14 \%$ to $13.29 \%$; $\mathrm{MgO}$ content of $0.00 \%$ to $0.36 \%$; $\mathrm{CaO}$ values of $0.04 \%$ to $0.56 \%$; $\mathrm{TiO}_{2}$ values of $0.22 \%$ to $0.95 \% ; \mathrm{K}_{2} \mathrm{O}$ values of from 0.28 to $2.43 \%$; $\mathrm{MnO}$ values of $0.01 \%$ to $0.12 \%$. The relatively high $\mathrm{Fe}_{2} \mathrm{O}_{3}$ is probably due to superficial oxidation and contamination by the Fe-rich percolating water from the highly ferruginous facies. Finally, geochemical compositions can give information about the origin of the alteration. From the major elements chemistry, the high $\mathrm{Fe}_{2} \mathrm{O}_{3}$ contents and the small $\mathrm{TiO}_{2}$ contents corroborate the meteoritic alteration because meteoritic alteration generally enhances the presence of the ferric oxides and hydroxides in tropical climate (Meunier et al., 1983; Santos et al., 2004).

\section{Mineralogy of geophagic clayey materials}


The mineralogical compositions of the Sabga geophagic clayey materials is rather heterogeneous and is mainly montmorillonite, kaolinite, associated with K-feldspars, plagioclase and quartz with small amounts of goethite, hematite and Ilmenite.

The results in wt\% of semi quantitative analysis of minerals identified in Sabga geophagic clayey materials are shown in table 2. Iron in the geophagic clayey materials is in the form of goethite, hematite and/or ilmenite.

\section{Physico-chemical of geophagic clayey materials}

The results of grain size, $\mathrm{pH}$, electrical conductivity, organic matter, water retention capacity, cation exchange, texture, colour and atterberg's limits are presented in Table 1. While the results of, bulk chemical analyses are presented in Table 2.

Soil $\mathrm{pH}\left(\mathrm{H}_{2} \mathrm{O}\right)$ was in the range of 4.1 to 5.6 with an average of 4.5 , Soil $\mathrm{pH}(\mathrm{KCl})$ was in the range of 3.4 to 4 with an average of 3.5. Compared to all five samples, SE registered the highest $\mathrm{pH}$. Electrical conductivity values ranged from $0.01 \mathrm{mS} / \mathrm{cm}$ to $0.02 \mathrm{mS} / \mathrm{cm}$ with a mean of $0.01 \mathrm{mS} / \mathrm{cm}$. Sand sized fractions ranged from 2 mass $\%$ (SD) to 6 mass \% (SB) with a mean of 3.6 mass \%. Silt varied from 31 mass \% (SC) to 45 mass \% (SD) whereas clay fraction was between 49 mass \% (SB) and 60 to 65 mass \% (SA and SC). The samples were generally clay in texture. Liquid limit ranged from 54.7 mass \% (SE) to 104.3 mass \% (SB) with a mean value of 86.84 mass \% whereas PL ranged from 44.6 mass \% (SE) to 85.5 mass \% (SD) with a mean of 65.44 mass \%. Plasticity index (PI) was between 10.1 mass \% (SE) and 40.8 mass \% (SA). Three samples, SC, SD and SE had plasticity index less than the mean of 21.40 mass $\%$.

Table 1: Physical characterization of geophagic clayey materials samples

\begin{tabular}{|c|c|c|c|c|c|c|c|}
\hline \multicolumn{2}{|c|}{ Sample } & SA & SB & $\mathrm{SC}$ & SD & SE & Mean \\
\hline \multicolumn{2}{|c|}{$\mathrm{pH}\left(\mathrm{H}_{2} \mathrm{O}\right)$} & 4.4 & 4.1 & 4.5 & 4,1 & 5.6 & 4.5 \\
\hline \multicolumn{2}{|c|}{$\mathrm{pH}(\mathrm{KCl})$} & 3.4 & 3.5 & 3.4 & 3.6 & 4 & 3.5 \\
\hline \multicolumn{2}{|c|}{$\mathrm{EC}(\%)$} & 0.02 & 0.01 & 0.02 & 0.02 & 0.01 & 0.01 \\
\hline \multicolumn{2}{|c|}{ OMC (\%) } & 4.15 & 3.99 & 4.15 & 5.20 & 5.20 & 4.53 \\
\hline \multicolumn{2}{|c|}{$\mathrm{OC}$} & 2.40 & 2.32 & 2.40 & 3.02 & 3.02 & 2.63 \\
\hline \multicolumn{2}{|c|}{ WRC (\%) } & 53.69 & 70.35 & 62.25 & 72.45 & 71.04 & 65.95 \\
\hline \multicolumn{2}{|c|}{ CEC (Meq / 100g) } & 43.28 & 28.40 & 39.60 & 27.60 & 26.96 & 33.16 \\
\hline \multirow[b]{2}{*}{ Texture } & Sand & 3 & 6 & 4 & 2 & 3 & 3.6 \\
\hline & Clay & 65 & 49 & 65 & 53 & 57 & 57.8 \\
\hline \multirow{4}{*}{$\begin{array}{l}\text { Atterberg } \\
\text { Limits }\end{array}$} & Silt & 32 & 45 & 31 & 45 & 40 & 38.6 \\
\hline & $\mathrm{LL}$ & 87.4 & 104.3 & 87.6 & 100.2 & 54.7 & 86.84 \\
\hline & PL & 46.6 & 79.6 & 70.9 & 85.5 & 44.6 & 65.44 \\
\hline & PI & 40.8 & 24.7 & 16.7 & 14.7 & 10.1 & 21.40 \\
\hline \multicolumn{2}{|c|}{ Colour } & $\begin{array}{l}\text { Light } \\
\text { gray }\end{array}$ & White & White & $\begin{array}{l}\text { Yellow } \\
\text { brown }\end{array}$ & $\begin{array}{l}\text { Yellow } \\
\text { brown }\end{array}$ & - \\
\hline \multicolumn{2}{|c|}{$\begin{array}{c}\text { Hue value and chroma of } \\
\text { samples }\end{array}$} & 7,5 YR 7/1 & $2,5 \mathrm{Y} / 8 / 1$ & $2,5 \mathrm{Y} / 8 / 1$ & $2,5 \mathrm{Y} \quad 6 / 3$ & $2,5 \mathrm{Y} / 6 / 3$ & - \\
\hline
\end{tabular}

\section{Mineralogy of Geophagic clayey materials}

Bulk rock mineralogy of representative samples are given on table 3. Montmorillonite + kaolinite + quartz $+\mathrm{K}-$ feldspars+ plagioclase \pm goethite \pm hematite \pm ilmenite were the identified mineral phases. Based on their relative intensities, the constituent minerals have been described in percentage.

Table 2: Bulk rock mineralogy of geophagic clayey materials samples

\begin{tabular}{|c|c|c|c|c|c|}
\hline Minerals (w\%) & SA & SB & SC & SD & SE \\
\hline Montmorillonite & 60 & 79 & 40 & 0 & 0 \\
\hline Kaolinite & 0 & 15 & 0 & 81 & 82 \\
\hline Total clay & 60 & 94 & 40 & 81 & 82 \\
\hline Quartz & 11 & 3 & 3 & 10 & 11 \\
\hline K-feldspars & 25 & 3 & 29 & 3 & 8 \\
\hline
\end{tabular}




\begin{tabular}{|c|c|c|c|c|c|}
\hline Plagioclase & 3 & 0 & 21 & 6 & 0 \\
\hline Goethite & 2 & 0 & 1 & 2 & 0 \\
\hline Hematite & 0 & 0 & 2 & 0 & 0 \\
\hline Ilmenite & Trace & Trace & Trace & Trace & Trace \\
\hline
\end{tabular}

Table 3: Bulk chemical of both major and trace elements analyses in oxides form of the sample from the different locations

\begin{tabular}{|c|c|c|c|c|c|c|}
\hline Major oxides (\%) & SA & SB & SC & SD & SE & HBC \\
\hline $\mathrm{SiO}_{2}$ & 64.84 & 47.11 & 47.73 & 41.86 & 56.95 & - \\
\hline $\mathrm{Al}_{2} \mathrm{O}_{3}$ & 12.75 & 23.41 & 21.18 & 20.52 & 22.09 & - \\
\hline $\mathrm{Fe}_{2} \mathrm{O}_{3}$ & 4.64 & 7.65 & 4.42 & 13.29 & 4.14 & 3.00 \\
\hline $\mathrm{MnO}$ & 0.03 & 0.01 & 0.11 & 0.12 & 0.11 & 0.05 \\
\hline $\mathrm{MgO}$ & 0.08 & 0.00 & 0.36 & 0.00 & 0.00 & - \\
\hline $\mathrm{CaO}$ & 0.39 & 0.15 & 0.56 & 0.04 & 0.16 & 0.10 \\
\hline $\mathrm{Na}_{2} \mathrm{O}$ & 0.44 & 0.10 & 0.77 & 0.10 & 1.78 & - \\
\hline $\mathrm{K}_{2} \mathrm{O}$ & 2.21 & 0.38 & 1.56 & 0.28 & 2.43 & - \\
\hline $\mathrm{TiO}_{2}$ & 0.22 & 0.74 & 0.29 & 0.69 & 0.95 & 0.20 \\
\hline $\mathrm{P}_{2} \mathrm{O}_{5}$ & 0.04 & 0.05 & 0.03 & 0.02 & 0.04 & - \\
\hline $\mathrm{P.F}$ & 12.29 & 19.60 & 20.55 & 20.07 & 10.08 & - \\
\hline $\begin{array}{c}\mathrm{Trace} \mathrm{elements} \\
(\mathrm{ppm})\end{array}$ & - & - & - & - & - & - \\
\hline $\mathrm{Zn}$ & 304 & 147 & 177 & 487 & 48 & 33 \\
\hline $\mathrm{Zr}$ & 892 & 1648 & 624 & 3607 & 1923 & 0.3 \\
\hline $\mathrm{Cu}$ & 20 & 23 & 39 & 20 & 19.1 & 1 \\
\hline $\mathrm{Ni}$ & 7.5 & 4.2 & 3.1 & 4.3 & 5.6 & 0.1 \\
\hline
\end{tabular}

HBC = Human Body Content (FAO/WHO, 2001)

\section{Discussion}

\section{pH of geophagic clayey materials}

The $\mathrm{pH}$ values of all the samples were generally lower than 7 indicating that they are slightly acidic thereby imparting a sour taste to the soil, as reported by Abrahams and Parsons (1997). This sour taste is one main reason why people, especially the pregnant women crave for this clay. Consumption of clay is reported to control excessive secretion of saliva and reduce nausea (Ibeanu et al., 1997). The values of the $\mathrm{pH}\left(\mathrm{H}_{2} \mathrm{O}\right)$ of all the samples were significantly higher than those of $\mathrm{pH}(\mathrm{KCl})$ indicating that the samples were all negatively charged. Ibeanu et al. (1997) reported the consumption of clay to control excessive secretion of saliva during pregnancy among women in Kenya and Nigeria. The use of soil to control secretion of saliva during pregnancy as reported by some women could be linked to the taste of the soil which in turn is related to soil $\mathrm{pH}$ and dissolved salts content. The $\mathrm{pH}$ values of all the samples analyzed were in the acidic range which would impart a sour taste to the soils. The sour taste may be beneficial during pregnancy to prevent excessive secretion of saliva and reduce nausea. The studied geophagic clayey materials samples have reasonable $\mathrm{pH}$ buffering capacity as indicated by the values of $\mathrm{pH}(\mathrm{KCl})$. When ingested, the $\mathrm{pH}$ of these soils is not likely to drop to the $\mathrm{pH}$ of the stomach because of this buffering capacity. The $\mathrm{pH}$ of the sampled soils as indicated in table 1 ranged from 4.1 to 5.6, meaning that soils were acidic. During the process of absorption, enzymes in the small intestines absorb the nutrients when they are at neutral pH (Lowe, 2002). Whatever reaches the small intestines (lumen) in an acid form, the enzyme (gastrin) responsible for nutrient absorption is not released (Wank, 1998).

\section{Electrical conductivity of geophagic clayey materials}

Electrical conductivity could be used to indicate the amount of dissolved salts in clays and soils (Ekosse, 2000; Ngole et al., 2006). The geophagic clayey materials all exhibited a very low EC, indicating that the amount of dissolved salts contained in them were very low. The taste of these geophagic soils from Sabga locality is not therefore likely to have been influenced by the salt content of the soils. The relationship between flocculation, soil pH and salt content has been reported by (Goldberg and Foster, 1990; Kotlyar et al., 1998). Flocculation in 
geophagic clayey materials may influence their ability to coat the intestinal mucosa. The coating creates a shield that protects the intestines from the acidic gastric juice. The very low salt content of these geophagic samples is not likely to have any influence on the degree of flocculation that may occur.

\section{Organic matter content of geophagic clayey materials}

Organic matter content in clayey materials is a source of nitrogen $(\mathrm{N})$ from which soil microbes could synthesise their proteins and DNA. Soils which are rich in OMC are therefore likely to harbour more bacteria and fungus some of which may be pathogenic. The range of values obtained for OMC content of the geophagic clayey materials $(2.32-3.02 \%)$ are similar to those in geophagic material from, Thailand, Uganda and Democratic Republic of Congo (Abraham and Parsons, 1997). Considering that the geophagic soils from Sabga locality had low levels of OMC, it is assumed that the pathogen load would also be low. The risk of bacterial infection including those of Staphylococcus aureus, Escherichia coli, Salmonella, shigella, penicillium solitum, alternaria Alternata, Aspergillus fumigatus and geohelminth infection such as those of Giardia Lamblia, Necator, Ancylostoma and Ascaris lumbricoides as a consequence of consuming these soils would be low.

\section{Water retention capacity of geophagic clayey materials}

Water retention is the ability of soils to process and hold large amounts of water (Brady and Weil, 1999). Geophagic clayey materials differ in terms of their WRC. Those with high clay content tend to have higher WRC compared to those with high sand content (Brady and Weil, 1999). The geophagic clayey materials from Sabga were clayey to silty in nature and would thus have considerable WRC. This property has been gainfully exploited in medicinal and pharmaceutical sciences where clays such as kaolin have been used to prepare formulations used in the treatment of diarrhea and other GI related ailments (Murdoch, 1985).

\section{Cation exchange capacity of geophagic clayey materials}

The pharmacological properties found in clays result in majority in their capacity from adsorption. This property is common to all clays but surely to variable degrees. Gastric acidity, arising from the excess production of hydrochloric acid in the stomach, can be effectively reduced by oral administration of non-systemic antiacids. Clay minerals can function as antiacids through adsorption of $\mathrm{H}^{+}$ions to surface sites. Thanks to the cation exchange capacity, clays have faculty to collect and fix the cations on their surface. Thus, clays tend to fix the protons on their surface and thus decreases the concentration of $\mathrm{H}^{+}$ions in stomach environment, from where their antiacid action. The phenomenon of adsorption can occur inside certain materials (case of materials rich in smectite) of which interlamellar space being mobile, they can fix ions between the layers. If interlamellar space is fixed (case of kaolinite), clays cannot fix ions between the layers. The ions fixed on the surface not having a solid connection are slackened in the stomach environment from where the feeling of improved symptomatology among certain patients but that reappear certainly a few hours later. This exchange increases the $\mathrm{pH}$ in stomach environment, because clays exchange its cations slightly bound by the protons $\mathrm{H}^{+}$. Consequently, the geophagic clayey materials of Sabga whose basic mineral is the smectite, would be more suitable for the relief of the gastric acidity compared to those whose basic mineral is kaolinite. According to Jade (2012), all clays are avid protons $\mathrm{H}^{+}$, and adsorb the hydrochloric acid in vitro. Studies undertaken by Severance et al. (1998), showed that the clayey materials which present a high CEC are more skilful to collect the cations in the gastro-intestinal tract. For soils to serve as supplements for any one nutrient, the nutrient must be sufficiently present in the available form in the soil. Availability of the nutrient in the soil and eventually in the stomach is influenced by the soil texture and mineralogy; OMC and pH which also influence soil CEC (Brady and Weil, 1999; Ngole et al., 2006). The CEC values of Sabga geophagic clayey materials are high, compared with those of geophagic clays of Balengou, Dschang and Calabar which vary between 2 and $17 \mathrm{meq} / 100 \mathrm{~g}$ (Njopwouo et al., 1998). Compared with those of pharmaceutical clays Smecta ${ }^{\circledR}$ whose basic mineral is montmorillonite (100-200 meq/100g) Ndzie (2009), geophagic clayey materials of the locality of Sabga are low.

\section{Texture and consistency limits of geophagic clayey materials}

Although the studied geophagic clayey materials were texturally dominated by clay, there was a considerable amount of silt and sand presents in the samples which may present some health risks. Because of their high clay content, the geophagic clayey materials from Sabga could also form a coating along the digestive tract mucosa, shielding the GI from diarrhea causing toxins and other toxic substances. This capability is enhanced by their acidic $\mathrm{pH}$ values, which according to Young et al. (2008) encourages clay flocculation. Silt and sand particles are 
dominated by quartz $\left(\mathrm{SiO}_{2}\right)$, a very hard mineral measuring seven (7) on the Mohr hardness scale. Dental enamel which is the main inorganic component of the human tooth, is dominated by hydroxylapatite $\left(\mathrm{Ca}_{5}\left(\mathrm{PO}_{4}\right)_{3}(\mathrm{OH}),(\mathrm{a}\right.$ calcium phosphate mineral), which is relatively softer than quartz.

It has a hardness of five (5) on the Mohr hardness scale. Due to its relative hardness compared to teeth, sand particles in geophagic clayey materials could cause damage to dental enamel through grinding, cracking, splitting and breakage during mastication. Studies carried out by King et al. (1999) indicated that medium sized sand (250

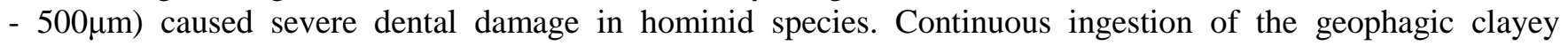
materials from Sabga locality, being sandier, would pose a greater risk of dental damage. Perforation of the sigmoid colon has been reported in some geophagic individuals (Woywodt and Kiss, 1999). According to Lohn et al. (2000) foreign bodies in the small intestines can cause perforation and the most important considerations of these bodies are the size, shape and nature of the object. Individuals ingesting the geophagic clayey materials from Sabga are at risk of intestinal perforations due to accumulation of quartz particles.

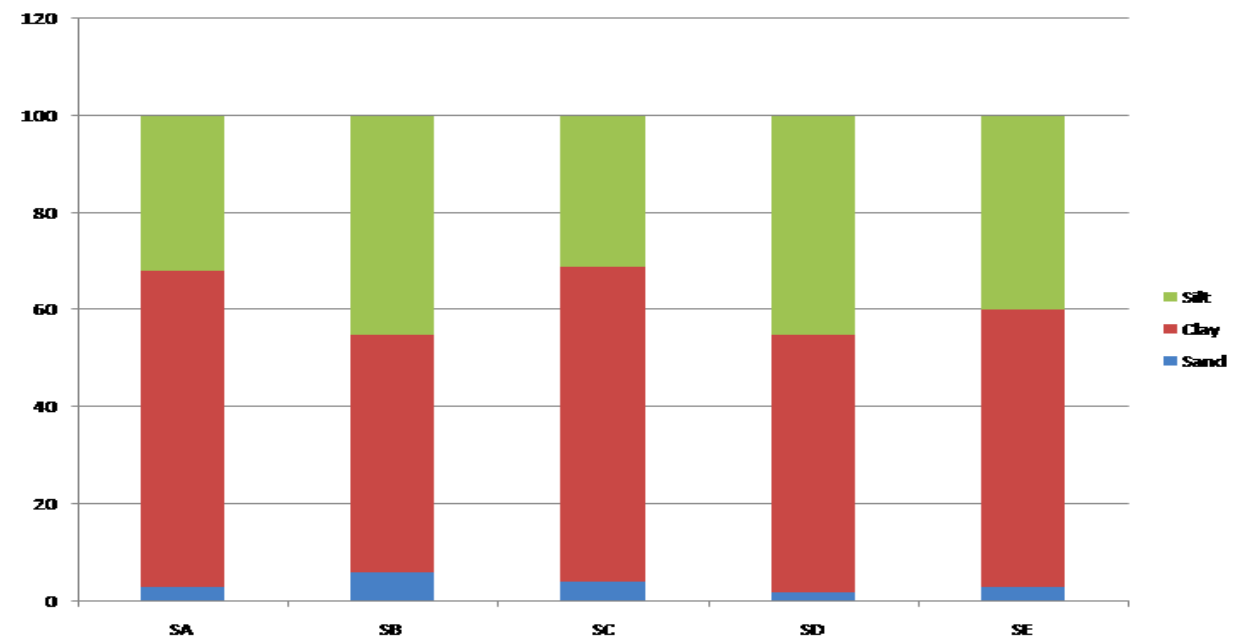

Figure 4: Grain Sizes of the different geophagic clayey materials samples.

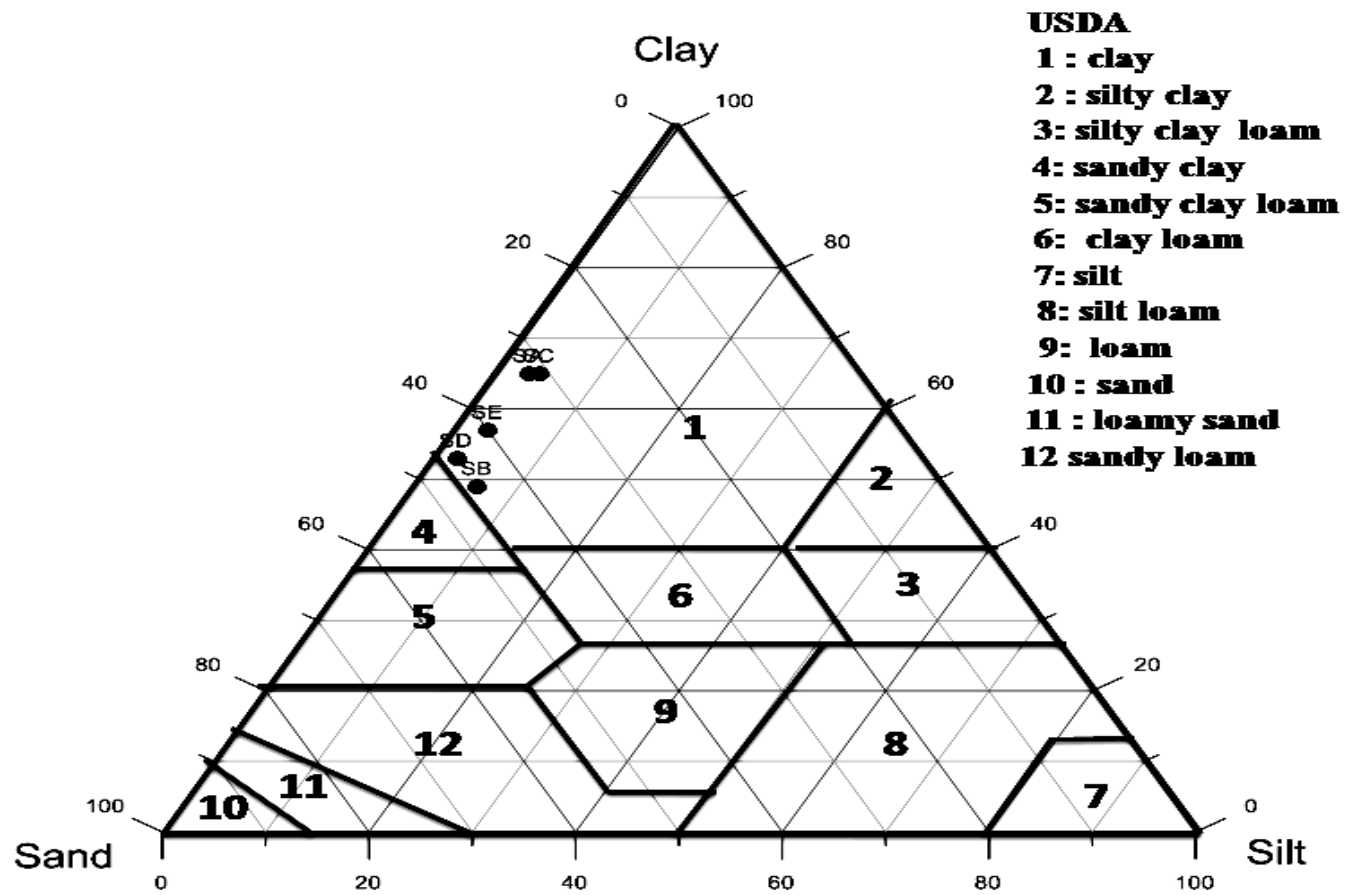

Figure 5: Textural triangle showing the textures of clayey materials samples from Sabga

The use of geophagic clayey materials to reduce salivation is defined by its ability to absorb moisture during mastication. This property of the geophagic clayey materials is based primarily on its consistency which in turn depends on the particle size distribution, type and amount of clay minerals and swelling potential of the soil 
(referred here as coefficient of activity) (Diko et al., 2012; Kormann, 2005). Geophagic clayey materials are characterized by a plasticity index (PI) between 10.1 and $40.8 \%$ (Table 1), belonging to the high plastic group. In the Holtz and Kovacs Diagram (1981) (figure 6), no sample corresponds to the mineralogy indicated.

With their (PI) values lower than 15\%, SD and SE are inappropriate for control excessive secretion of saliva during pregnancy. With (PI) values above $15 \%$, SA, SB, SC might be used to control excessive secretion of saliva during pregnancy. From the results, the samples display high plasticity (figure 6) with a normal to inactive swelling potential (figure 7). Consistency limits of Sabga geophagic clayey materials suggests increasing suitability for use as a remedy for excessive salivation, except kaolinitic samples SD and SE we have a inactive swelling potential (figure 7).

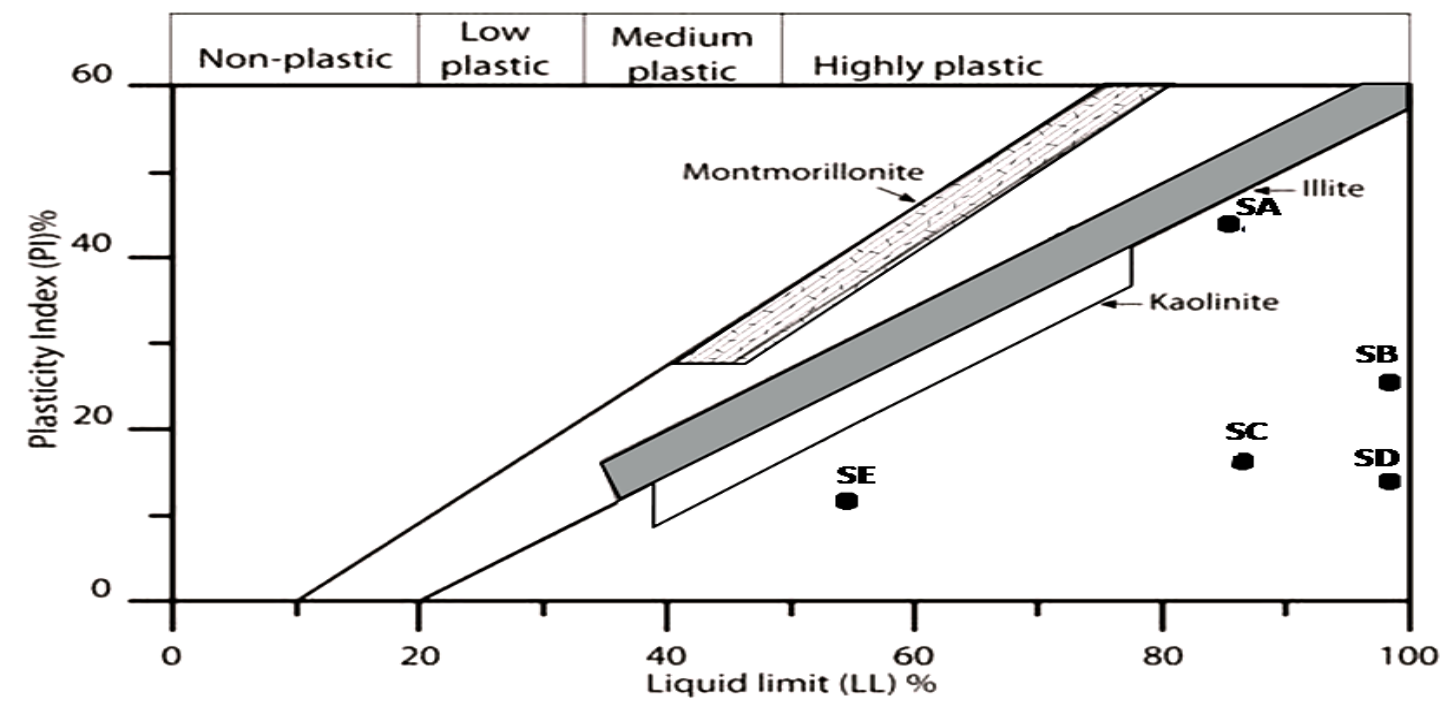

Figure 6: Position of geophagic clayey materials samples SA, SB, SC, SD and SE on the Holtz and Kovacs diagram (Holtz \&Kovacs, 1981)

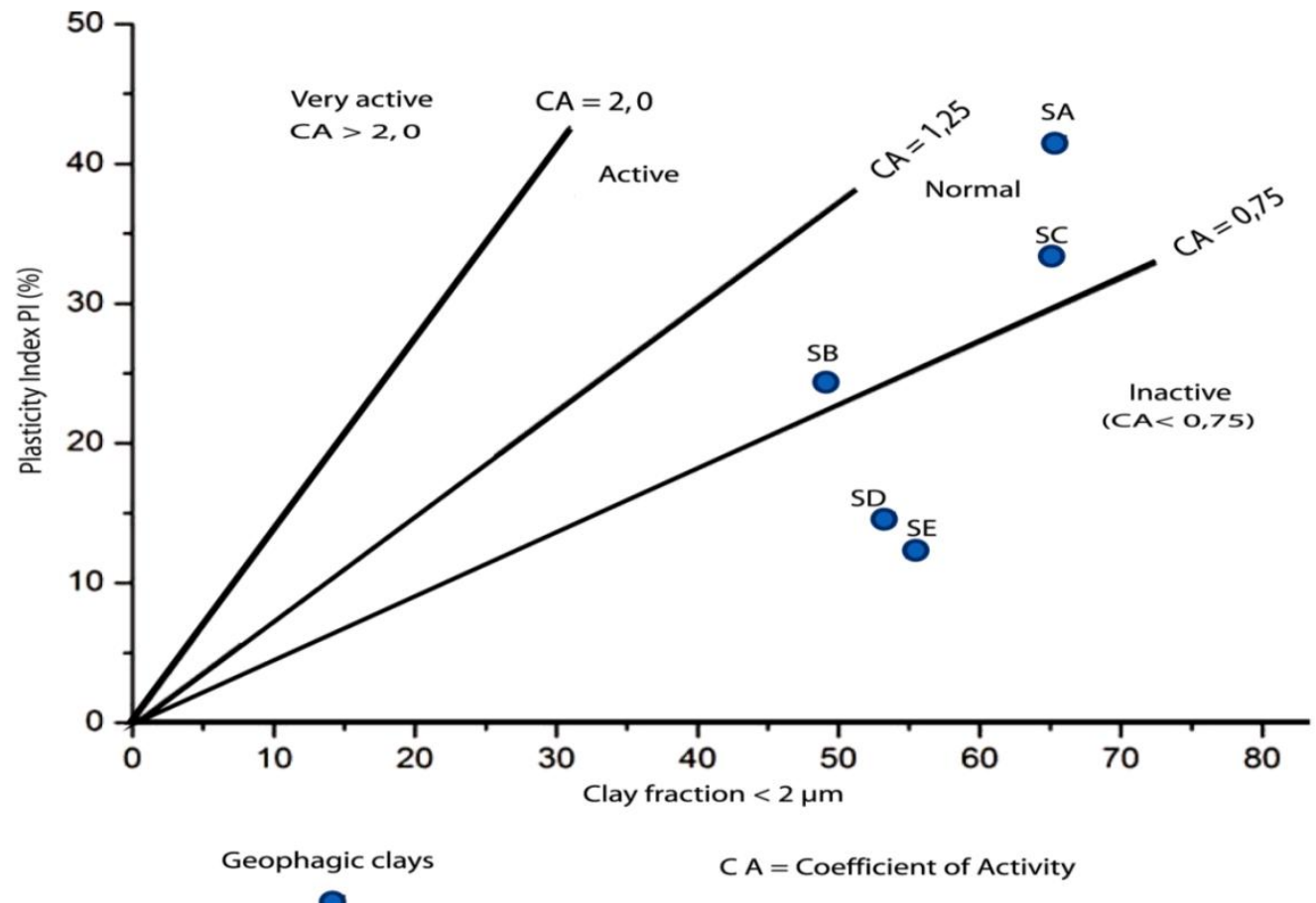

Figure 7: Activity diagram of geophagic clayey materials from Sabga locality

\section{Mineralogy of geophagic clayey materials}

These geophagic clayey materials may impact positively or negatively on human health when ingested. Kaolin and smectite can be used to treat diarrhea, gastritis, colitis. The coarse sandy quartz particles in geophagic clays 
could affect dental enamel and also lead to the possible rupturing of the sigmoid colon due to the abrasive nature of the particles Woywodt and Kiss (2002).

The concomitant administration of drugs with kaolinite, such as amoxicillin, ampicillin, atropine, cimetidine, clindamycin, digoxin, phenytoin, quinidine, and tetracycline could reduce drug absorption and should be avoided. Equally, it has been shown that smectites can adsorb amphetamine sulfate, tetracycline, tolbutamide, warfarin sodium, and diazepam (Elmore, 2003; Rowe et al., 2003, 2006).

Consequently, their consumption by geophagism during a treatment under drug quoted above is strictly prohibited. No minerals can function as antiacids through mechanism of neutralization of gastric acid in stomach were identified in the mineralogical composition of geophagic clayey materials.

\section{Geochemistry of geophagic clayey materials}

The elemental composition of geophagic clayey materials in Sabga locality are compared to the adequate daily intake of trace elements in the human body (as shown in Table 3), the trace element content of the geophagic clayey materials in Sabga locality is relatively high. The $\mathrm{Cu}$ content in the geophagic clayey materials have a range of 19.1 to $39 \mathrm{ppm}$ while daily intake necessary for human body function is only $1.0 \mathrm{ppm}$. The values of other trace elements like $\mathrm{Zr}(624-3607 \mathrm{ppm}), \mathrm{Zn}(48-304 \mathrm{ppm})$ and $\mathrm{Ni}(3.1-7.5 \mathrm{ppm})$ are higher than the values for daily intake necessary for human body function of $\mathrm{Zr}(0.3 \mathrm{ppm}), \mathrm{Zn}(33 \mathrm{ppm})$ and $\mathrm{Ni}(0.1 \mathrm{ppm})$ respectively. The values of major oxides like $\mathrm{Fe}_{2} \mathrm{O}_{3}, \mathrm{TiO}_{2}$ and $\mathrm{MnO}$ are higher than the values needed for human body function (table 3). Sabga geophagic clayey materials may introduce heavy metals like $\mathrm{Fe}, \mathrm{Zn}, \mathrm{Cu}, \mathrm{Mn}, \mathrm{Ni}$, Ti, and $\mathrm{Zr}$ to the gastrointestinal system of consumers, which can cause an increase of metals in the organism, if they are absorbed.

\section{Conclusions}

This article has examined the physico-chemical characteristics of geophagic clayey materials from Sabga locality. It has attempted to elucidate on reasons advanced by geophagic individuals engaged in the practice. Based on results obtained, the low CEC of the studied geophagic clayey materials, exchangeable $\mathrm{H}^{+}$and other related cations may not be adsorbed, consequently, its geophagic clayey materials would not be inappropriate for the relief the gastric acidity. The acidic nature of the geophagic clayey materials gives a sour taste which is mostly coveted by pregnant women in overcoming nausea and excess salivation. Acid character of the geophagic clayey materials predisposes consumers at the enormous risks of severe anaemia, because during the process of absorption, enzymes in the small intestines absorb the nutrients when they are at neutral $\mathrm{pH}$. Possible human health shortcoming in the ingestion of the geophagic clayey soils would include dental enamel damage and perforation of the sigmoid colon. Absorption of water from the gastro intestinal tract is a possibility, considering their high WRC. Mineral phases identified in the geophagic clayey materials included montmorillonite, kaolinite, K-feldspars, plagioclases, quartz, goethite, hematite and ilmenite.

\section{References}

Abrahams PW., Parsons JA (1997). Geophagy in the Tropics: An appraisal of three geophagical materials. Environ. Geochem. Health, 19(1): 325- 334.

Banenzoue Charles (2017). Argiles consommées par géophagisme au Cameroun: Caractérisation physicochimique, thermique et propriétés antiacide. Thèse de doc. $3^{\mathrm{e}}$ cycle, Univ. Yaoundé I, 187p.

Bonglaisin J N., Mbofung C M., Lantum D N (2011). Intake of Lead, Cadmium and Mercury in Kailon eating: A Quality Assessment. Journal of Medical Sciences, 11(7):267 273.

Boski T., Pessoa J., Pedro P., Thorez J., Dias J M A., Hall I R (1998). Factors governing Abundance of Hydrolyzable Amino Acids in the Sediments from the N.W. European Continental Margin $\left(47-50^{\circ} \mathrm{N}\right)$. Progress in Oceanography 42, 145-164.

Brady N C., Weil R R (1999). Practical Nutrient Management. The nature and Properties of Soils, 12th edn., Prentice Hall, New Jersey, USA.

Carretero M (2002). Clay minerals and their beneficial effects upon human health. A review Appl Clay Sci 21: 155-163.

Cook H E., Johnson P D., Matti J C., Zemmels I (1975). Methods of Sample Preparation and X-ray Diffraction in X-ray Mineralogy Laboratory. Deep Sea Drilling Project, University of California, Riverside. Contribution $\mathrm{n}^{\circ} 74-5,999-1007$. 
Diko M L., Ekosse G E., Ayonghe S N., Ntasin E B. (2012). Physical and geotechnical characterization of unconsolidated sediments associated with the 2005 Mbonjo landslide, Limbe (Cameroon). International Journal of Physical Sciences 7(20): 2784 - 2790.

Diko and Ekosse (2014). Soil Ingestion and Associated Health Implications: A Physicochemical and Mineralogical Appraisal of Geophagic Soils from Moko, Cameroon. African Journal of Traditional Complementary and Alternate Medicine.Ethno Med, 8(1): 83-88.

Diko M L., Siewe épse Diko C N (2014). Physico-chemistry of geophagic soils ingested to relief nausea and vomiting during pregnancy. African Journal of TraditionalComplementary and Alternate Medicine, 11(3):21-24.

Dominy J N., Davoust E., Minekus M (2004). Adaptive function of soil consumption: an in-vitro study modeling the human stomach and small intestine. J. Exp. Biol. 207: 319-324.

Douola Ninla A. (2008). Etude géologique et caractérisation minéralogique et chimique des matériaux argileux de Méka'a (Foréké Dschang). Thèse de Master des Sciences de la Terre de la Faculté des Sciences de l'Université de Dschang. 65p.

Ekosse G (2000). The Makoro kaolin deposit, south eastern Botswana: Its genesis and possible industrial applications. Appl. Clay Sci. 16(5- 6): 301-320.

Ekosse G E., de Jager L., Ngole V (2010). Traditional mining and Mineralogy of geophagic clays from Limpopo and Free State Provinces, South Africa. Afr J Biotechnology 9: 8058-8067.

Ekosse G E., Anyangwe S (2012). Mineralogical and particulate morphological characterization of geophagic clayey soils from Botswana. Bulletin of then Chemical Society of Ethiopia, 26(3): 373-382.

Emofurieta WO, Kayode AA, Coker SA (1992). Mineralogy, geochemistry and Economic evaluation of the kaolin deposits near Ubulu-Uku, Awo-Omama and Buan in southern Nigeria. Journal of Mining and Geology 28: 211-220.

Fagel N., Boski T., Likhoshway L., Oberhaensli H (2003). Late Quaternary clay mineralrecord in Central Lake Baikal (Academician Ridge, Siberia). Paleogeography, Paleoclimatology, Paleoecology, 193, 159-179.

Goldberg S., Forster H S (1990). Flocculation of reference Clays and Arid-Zone soil clays. Soil Sci. Soc. Am. J. 54: 714-718.

Holtz R D et Kovacs W D (1981). An introduction to Geotechnical Engineering, Prentice-Hall, Englewood Cliffs, New Jersey, pp. 77-107.

Ibeanu GEL, Dim LA, Mallam SP, Akpa TC, Munyithya J (1997). Nondestructive XRF analysis of Nigerian and Kenyan clays. J Radioanal Nucleic Chem 221: 207-209.

Jade Allègre (2012). Les silicates d'alumines (argiles) une pratique coutumière ancienne relayée dans la médécine moderne. Thèse de Doctorat Médecine, Université de Paris Nord. France 134 p.

Kamgang P., Njonfang E., Chazot G. \& Tchoua F (2007). Géochimie et géochronologie des laves des monts Bamenda (ligne volcanique du Cameroun). Comptes Rendus Geosciences, 339, 659-666.

Kamgang P., Njonfang E., Chazot G., Tchoua F (2008).Geochemistry and geochronology of mafic rocks from Bamenda Mountains (Cameroon): Source composition and crustal contamination along the Cameroon Volcanic Line. Comptes Rendus Geoscience, 340, 850-857.

King T., Andrews P., Boz B(1999). Effect of taphonomic processes on dental microwear. Am. J. Phys. Anthropol., 108(3): 359373.

Kornmann M (2005). Matériaux de construction en terre cuite. Septima. 275p.

Kotlyar I S., Sparks B D., Lepage Y., Woods J R (1998). Effect of particle size on the flocculation behaviour of ultra-fine clays in salt solutions. Clay Miner, 33: 103-107.

Lohn JWG., Austin RCT., Winslet MC (2000). Unusual causes of small-bowel obstruction. J. R. Soc. Med. 93: 365-368.

Lowe M E (2002). The triglyceride lipases of the pancreas. Journal of Lipids Res, vol. 43, pp 2007-2016.

Meunier A., Velde B., Dudoignon P., Beaufort D (1983). Identification of weathering and hydrothermal alteration in acidic rocks: petrography and mineralogy of clay minerals. Sci. Géol., Mém., 72, Strasbourg, 93-99.

Munsell Soil Colour Charts (1992). The Munsell Soil Colour Book. Colour charts, Munsell Colour Company Inc., MD 2128, Newburgh, USA.

Murdoch D B (1985). Kaolin as treatment for diarrhoea. Vet. Record, 116(9): 247-248. 
Ndzie Etoa M C (2009). Utilisation empirique des argiles brutes dans des pathologies digestives. (Observation de la ville de Dschang). Thèse de doctorat en médecine, 103 p.

Ngole V M., Mpuchane S., Totolo O (2006). The effect of ageing on fertilizer value of sludge from Botswana. J. Appl. Sci. Environ. Manage. 10: 109-115.

Ngole V M., Ekosse G E., De Jager L., Songca S P (2010). Physicochemical Characteristics of Geophagic Clayey Soils from South Africa and Swaziland. African Journalof Biotechnology 9 (36): 5929-5937.

Ngole V M and Ekosse G E (2012). Physico-chemistry, mineralogy, geochemistry and nutrient bioaccessibility of geophagic soils from Eastern Cape, South Africa.Scientific Research and Essays Vol. 7(12), pp. 13191331

Njopwouo D., Téjiogap E., Sondag F., Volkoff B., Wandji R (1998). Caractérisations minéralogiques et chimiques des argiles consommées par géophagisme au Cameroun. Ann. Fac. Sci., Univ. Ydé I, 31 (2), 319-334.

Santos M C., Varajao A F., Yvon J (2004). Genesis of clayey bodies in Quadrilàtero Ferrifero, Minas Gerais, Brazil. Catena 55, 277-291.

Severance HW., Holt T., Patrone NA., Chapman L (1988). Profound muscle weakness and hypokalemia due to clay ingestion. South Med. J. 18: 272-274.

Rowe R C., Sheskey P J., Weller P J (2003). Handbook of Pharmaceutical Excipients. 4th ed. Pharmaceutical Press and the American Pharmaceutical Association.

Rowe R C., Shesley P J., Owen S C (2006). Pharmaceutical Excipients. Pharmaceutical Press, London.

Van Reeuwijk L P (2002). Procedures for Soil Analysis. International Soil Reference and Information Centre (ISRIC) Technical paper 9.

Wank M P (1998). South Africa: Molecular cloning of the helodermin and exendin-4c DNAs in the Lizard. Relationship to vasoactive intestinal polypeptide/ pituitary adenylate cyclase activating polypeptide and glucagon-like peptide and evidence against the existence of mammalian.

Woywodt A and Kiss A (1999). Perforation of the sigmoid colon due to geophagia. Arch. Surg. 134 (1): 88-89.

Woywodt A and Kiss A (2002). Geophagia: the history of earth-eating. J Roy Soc Med 95: 143-146.

Young S L., Wilson M J., Miller D., and Hillier S (2008). Toward a comprehensive approach to the collection and analysis of pica substances, with emphasis on geophagic materials, Plos One, vol. 3, p.3147. 